DOI: $10.29141 / 2218-5003-2021-12-4-4$

JEL Classification: M31

\title{
Customer emotions when making an online purchase decision: Results of neuromarketing experiments
}

\section{Olga B. Yarosh' ${ }^{1}$, Natalya N. Kalkova' ${ }^{1}$, Viktor E. Reutov'}

${ }^{1}$ V.I. Vernadsky Crimean Federal University, Simpheropol, Russia

\begin{abstract}
The primary task of marketing is to establish consumers' emotional connection with a product and awake emotions that motivate them to make a purchase. Deciphering buyers' emotional state when making a purchase decision allows designing effective and responsive interfaces to market and promote products online. The study aims to identify the emotions acting as predictors of consumer choice when ordering ready-made meals online. Methodologically, the research rests on marketing and neuromarketing theories of studying consumer behavior that make it possible to determine sensory modalities at different stages of the consumer-product interaction. In accordance with the methodology, marketing (cognitive assessment of events) and neuromarketing (experiments using an eye tracker, face reader and computer polygraph) research methods were applied. Data processing was carried out using SPSS 22.0 software, and the following statistical methods were utilized: the Kolmogorov-Smirnov test, the nonparametric Mann-Whitney $U$ test and Kruskal-Wallis $H$ test, the parametric Student's $t$-test, as well as correlation, variance and regression analysis. The information base includes a series of controlled neuromarketing experiments using an eye tracker, an emotion classifier and a computer polygraph, as well as the authors' algorithms and calculations. The experimental results demonstrate that virtual shelf placement and on-shelf visibility have no effect on product choice. At the stage of purchase, the prevailing stereotypical relationship to the product is of high importance. The research results show that customer choice is usually accompanied by a change in the emotional valence from disgust, fear and sadness to surprise and enjoyment. Statistically significant differences in the emotional states of men and women when making online choices were found in relation to such emotions as surprise, enjoyment, disgust and anger, and were not found in relation to sadness and fear. Positive mood, if evoked by a particular product, leads to customers preferring this product to broaden the positive experience, whereas negative emotions on the contrary encourage people to choose products incompatible with the current level of emotional arousal.
\end{abstract}

Keywords: neuromarketing; customer behaviour; information asymmetry; emotions; purchase; Internet; decision-making; ready-made meals.

Funding: The study was funded by the Russian Foundation for Basic Research (RFFI) within the framework of the research project No. 20-010-00473 A "Examining information asymmetry based on neuromarketing methods and algorithms".

Paper submitted: July 1, 2021

For citation: Yarosh O.B., Kalkova N.N., Reutov V.E. (2021). Customer emotions when making an online purchase decision: Results of neuromarketing experiments. Upravlenets - The Manager, vol. 12, no. 4, pp. 42-58. DOI: 10.29141/2218-5003-2021-12-4-4.

\section{Эмоции потребителей в процессе принятия решения об онлайн-покупке: результаты нейромаркетинговых экспериментов}

\author{
О.Б. Ярош' ${ }^{1}$, Н.Н. Калькова' ${ }^{1}$ В.Е. Реутов ${ }^{1}$
}

${ }^{1}$ Крымский федеральный университет им. В.И. Вернадского, г. Симферополь, РФ

\begin{abstract}
Аннотация. Основная задача маркетологов при осуществлении продаж - создать эмоциональную связь с потребителем и вызвать побуждающие к покупке эмоции. Понимание эмоционального состояния позволяет разрабатывать эффективные, осмысленные и «отзывчивые» интерфейсы для продвижения продукции в Интернете. Статья посвящена выявлению эмоций, являющихся предикторами потребительского выбора при заказе готовой еды с помощью интернет-ресурсов. Методология исследования базируется на маркетинговых и нейромаркетинговых теориях изучения потребительского поведения, позволяющих выявить сенсорные модальности на разных этапах взаимодействия потребителя с продуктом. В соответствии с методологией применялись маркетинговые (когнитивная оценка событий) и нейромаркетинговые (эксперименты с использованием айтрекера, фэйсридера и компьютерного полиграфа) методы исследования. Обработка данных проводилась в программе SPSS 22.0, использовались следующие статистические методы: тест Колмогорова - Смирнова, непараметрические тесты Манна - Уитни и Краскала - Уоллиса, параметрический $t$-тест Стьюдента, корреляционный, дисперсионный и регрессионный анализ. Информационной базой исследования являются результаты серии контролируемых нейромаркетинговых экспериментов с применением айтрекера, классификатора эмоций и компьютерного полиграфа, а также авторские алгоритмы и расчеты. Результаты экспериментов показали, что на выбор продукта не влияют его расположение на виртуальной полке и визуальная заметность. На этапе покупки важно сложившееся стереотипное отношение к продукту. Установлено, что потребительский выбор обычно сопровождается изменением валентности эмо-
\end{abstract}


ций с отвращения, страха и печали на усиление удивления и радости. Статистически значимые различия в эмоциональных состояниях мужчин и женщин при выборе в Интернете обнаружены в отношении эмоций удивления, радости, отвращения и гнева и не обнаружены в отношении эмоций печали и страха. Позитивное настроение, как правило, обусловливает предпочтение поддерживающих его продуктов, тогда как отрицательные эмоции, напротив, побуждают выбирать товары, несовместимые с текущим уровнем эмоционального возбуждения.

Ключевые слова: нейромаркетинг; поведение потребителей; информационная асимметрия; эмоции; покупка; Интернет; принятие решений; еда.

Финансирование: Исследование выполнено при финансовой поддержке РФФИ в рамках научного проекта № 20-010-00473 А «Исследование информационной асимметрии на основе методов и алгоритмов нейромаркетинга».

Дата поступления статьи: 1 июля 2021 г.

Ссылка для цитирования: Ярош О.Б., Калькова Н.Н., Реутов В.Е. (2021). Эмоции потребителей в процессе принятия решения об онлайн-покупке: результаты нейромаркетинговых экспериментов // Управленец. T. 12, № 4. C. 42-58. DOI: $10.29141 / 2218-5003-2021-12-4-4$.

\section{INTRODUCTION}

With the emergence of novel business strategies associated with the implementation of the digital economy model, an increasing number of questions arise regarding the causes and motives of consumer behavior and emotional states that affect a buying decision process. Recent studies have demonstrated that customers make most their purchasing decisions following a thorough analysis of the product's advantages and disadvantages [Consoli, 2009, p. 996], and emotions are inherent in the decision-making and selection process and often serve as activators of a positive experience of interaction between the buyer and the brand [Yarosh, Kalkova, Reutov, 2020]. Relationship marketing premised on the principles of emotional marketing is the driving force behind Marketing 4.0. Typically, customers hunt for products or services that meet their needs. Purchasing decisions are driven by two types of needs: functional and emotional. Products available in the market are highly unified, which leads to customers buying not the product as such, but its emotional perception [Mazur, 2012, p. 16]. Therefore, the main task of marketers when selling a product is to awaken the relevant emotions that arise while using the product, as well as to create an emotional connection by offering a customer experience of interaction [Barnes, Southee, Henson, 2003, p. 134].

The purpose of the paper is to conduct an experimental study of emotions as predictors of consumer choice. To accomplish the stated purpose, we formulate the following objectives:

1) to carry out a statistical assessment of the significance of the differences between visual attention to a product and a purchasing intent;

2) to identify an array of emotions indicating a buyer's intention to test or purchase a product, and to determine the relationship between consumer interaction experience and product loyalty;

3) to ascertain the correlation between verbal and non-verbal factors in choosing a product online;
4) to perform a synchronous study of the emotional states of consumers based on a combination of different neuromarketing and cognitive methods to identify the levels of multimodal perception of the product.

\section{THEORETICAL OVERVIEW}

First attempts to comprehend the mechanisms underlying human emotionality have been undertaken as far back as the time of Aristotle. Interest in studying facial appearance and physiognomy was first indicated in the 4th century BC [Highfield, Wiseman, Jenkins, 2009, p. 12]. After a long period of obscurity, the interest in the topic was reignited in the $17^{\text {th }}$ century. In 1649, John Bulwer examined various facial expressions and head movements. In 1734, Bruno's fundamental physiognomy work was published ${ }^{1}$. It is noteworthy that in the era of the Enlightenment, Descartes questioned the nature of the relationship between spirit and body and began to distinguish between the influence of reason and emotion [Descartes, 1989, p. 24]. Face and facial expressions were actively studied in the $18^{\text {th }}$ century by artists and actors, primarily for finding the ways to convey shades of emotions in culture and art.

Charles Darwin [1904, p. 43] made a serious scientific breakthrough in the study of emotions in 1872 . He first came up with the idea that by using their facial expressions people pass on communicative information without saying a word. In his work" The Expression of the Emotions in Man and Animals", the scientist demonstrated the similarities between the nervous reactions of living organisms to external influences. In addition, Darwin grouped various types of facial expressions in generalized categories and cataloged facial muscles demonstrating certain expressions. It was shown that emotions tend to evolve as a person matures. Infant is able to experience basically only pleasure and pain and clearly distinguish between good

\footnotetext{
${ }^{1}$ References to these works are available in [Darwin, 1904].
} 
and bad emotions, then as they grow older, emotions become more complex, which is associated with the process of brain development [Hess et al, 1992, p. 251].

The work of the Canadian psychologist Paul Ekman initiated in the 1970s was an important milestone in studying facial expressions [Ekman, Friesen, 1977, p. 56]. He identified six basic emotions (anger, surprise, disgust, enjoyment, fear, and sadness) and showed that members of different cultures and ethnic groups express their emotions in a similar way as emotions are a universal non-verbal language to communicate information. Paul Ekman's work underlay the development of modern systems for automatic recognition of facial expressions and the use of technologies in studying emotional states.

The first step towards the automatic recognition of facial expressions was the Suwa system presented in 1978 [Samal, lyengar, 1992] which provided sequential analysis of movie frames using twenty tracking points. It did not become widespread, since in the 1980s there was no comparatively cheap computing power to perform such algorithms. By the early 1990s, the development of reliable detection methods and the mass use of computers renewed interest in automatic emotion recognition [Boehner et al., 2007, p. 275]. The six emotions identified by Ekman were recognized as basic; however, in 2000, W. Gerrod Parrott found that human facial muscles were able to express 136 emotions [Parrott, 2000, p. 34]. Plutchik [1997, p. 17] singled out eight primary emotions categorized into four pairs. Bindu, Gupta and Tiwary [2007, p. 351] developed a model which classified 22 emotions.

Currently, automatic emotion recognition systems are actively used in various fields [Aharonson, Nehmadi, Messer, 2007, p. 333]. With the development of robotics, the intensifying interaction of robotic systems with humans and the emergence of phygital marketing, there has been a particular interest in neuromarketing works aimed at exploring emotional states [Jordan, 2001, p. 303], since it is the understanding of emotions that allows one to develop more effective, meaningful and responsive interfaces for promoting products to the consumer [Morin, Renvoise, 2020, p. 45].

\section{RESEARCH METHODOLOGY}

Neuromarketing experiments do not need the number of samples to be large to prove the results are valid, since due to the hardware support they generate large amounts of biometric data obtained from each of the subjects, which allows running reliable statistical tests. The present study involved 29 people: 15 men (aged 18-22), and 14 women (aged 18-35). A series of experiments involving combined research methods (Table 1) made it possible to evaluate the participants' conscious and unconscious reactions to the visual representation of ready-made meals ordered via the Internet. All respondents signed an informed consent form to participate in the experiments, and none of them reported a history of neurological or mental illness or vision or hearing impairment.

1. While choosing ready-made meals, visual attention to the product was studied using the VT3 mini eye tracker, which allows registering the respondents' eye movements. This tool-based method makes it possible to examine oculomotor behavior including fixations (time interval during which the eyes focus on an object for 200-300 msec) and saccades (movements of both eyes between two fixations lasting from 40 to $50 \mathrm{msec}$ ). This technique establishes visual attention to a particular object, but does not provide answers to the question about the valence of the area of interest. It is impossible to say for sure that the visibility of an object is caused by positive or negative emotions (one might be looking at it for a long time, because he/she is confused and does not understand what is being shown to them). Therefore, we used eye tracking as an auxiliary tool that allows us to identify areas of interest and obtain heat maps for the presented visual stimuli.

2. Respondents' emotions were analyzed using the experimental methods for studying facial movements. Currently, there are two technologies capable of doing so: (1) the Facial Action Coding System (FACS) adopted by Paul Ekman and Wallace V. Friesen in 1977 [Ekman, Friesen, 1977, p. 56], and (2) the Face Animation Parameter (FAP) developed by the Moving Pictures Experts Group (MPEG) in 1999. Both technologies are closely related and the principles of their work are quite similar [Dornaika,

Table 1 - Methods and tools of analysis Таблица 1 - Методы и инструменты анализа

\begin{tabular}{|c|c|c|}
\hline Method & Tool & Measurement \\
\hline \multirow{3}{*}{ Neuromarketing } & $\begin{array}{l}\text { Eye tracker VT3 mini with a sample rate of } \\
250 \mathrm{~Hz} \text { with EventID software }\end{array}$ & $\begin{array}{l}\text { Product visibility, a proportion of fixations on each area of inter- } \\
\text { est (AOI), msec [Yarosh et al., 2020, p. 78] }\end{array}$ \\
\hline & $\begin{array}{l}\text { Facial Action Coding System (FACS) with Emo- } \\
\text { Detect software }\end{array}$ & $\begin{array}{l}\text { Calculating the likelihood of emotional arousal, studying } \\
\text { the range of emotions experienced }\end{array}$ \\
\hline & The RIF polygraph with Sheriff 7 software & $\begin{array}{l}\text { Evaluating the intensity of emotional arousal according to gal- } \\
\text { vanic skin response (GSR) and photoplesiogram (PPG) }\end{array}$ \\
\hline Marketing & Survey & Consumer preferences for the visualized products \\
\hline
\end{tabular}


Davoine, 2008, p. 257]. In the present paper, we applied the FACS technology, since it acts as the backbone of the software algorithm for processing and two-dimensional classification of facial micro-expressions based on data received from a webcam and processed in the EmoDetect software.

This method allows identifying the presence of a particular emotion by a probabilistic method using the ViolaJones object detection. Through this method, one can calculate the likelihood of the occurrence of the six emotions during the stimulus, but cannot provide information about the intensity of emotional arousal.

3. The intensity of emotional arousal was assessed by the autonomic (vegetative) body reactions: heart rate, blood pressure, galvanic skin response (GSR), and photoplesiogram (PPG). These sensors are used in modern computerized polygraphs and provide a fair view of unconscious arousal caused by a visual stimulus. For instance, using GSR it is possible to perform a quantitative assessment of the level of emotional arousal and the magnitude of stress. This reaction results from the fact that skin is able to conduct electricity due to changes in the activity of human sweat glands.

4. Cognitively, the events were assessed through a survey to identify respondents' attitudes towards the type of products presented and to determine consumer preferences. The dependent variable was the respondent's emotional state; the independent variable was a list of factors that guided the respondent when choosing a product (product location, taste preferences, product design, and the desire to try something new).

The experiments were designed and performed at the Laboratory of Neuromarketing and Behavioral Economics of the V.I. Vernadsky Crimean Federal University. They implied presenting various visualizations of ready-made meals on a computer monitor in a controllable way. The data were processed using the SPSS 22.0 software. The following statistical methods were applied: the Kolmogorov-Smirnov test, the nonparametric Mann-Whitney $U$ test and Kruskal-Wallis $H$ test, the parametric Student's $t$-test, as well as correlation, ANOVA and regression analysis [Moosmüller, Rebik, 2018, p. 20].

The experiments consisted of the following stages.

At Stage 1, an eye tracking experiment was carried out. The respondents were presented with 14 groups of finished products arranged at the same distance from each other on 42 variants of virtual shelves. Time available for investigating them was unlimited. While demonstrating the products, respondents were asked about their preferred meals. As a result of the study, an array of 2053 data sets of oculomotor behavior was obtained, which became the basis for developing heat maps and further processing in the OGAMA software.

Hypothesis 1: There is an asymmetry in the visual attention to the product depending on its placement on the virtual shelf and purchasing intent.
Hypothesis 2: There is a correlation between the prod- $\frac{0}{2}$ uct's on-shelf visibility and a buyer's decision to purchase it. ㄱำ

At Stage 2, we conducted an experiment to investigate respondents'emotional state. The participants were asked to express their opinions about the presented products. They were shown virtual shelves while their facial muscles movements and the FACS six basic emotions were identified and synchronously recorded using the EmoDetect software. Moreover, the galvanic skin response, which is based on calculating their tonic and physical activity, was also synchronously registered. Then the data were processed and low-pass filters were applied to detect sweat peaks in the GSR signal.

Hypothesis 3: There are significant differences in the emotional states of men and women while choosing ready-made food online.

Hypothesis 4: Emotions are the antecedents of consumer choice.

At Stage 3, respondents were given a questionnaire concerning the factors they believed to be the most important for them when choosing ready-made food and ordering it via the Internet. The survey was held verbally, and GSR and PPG data were recorded synchronously to determine autonomic responses to the questions, which made it possible to identify significant non-verbal factors for the subject.

Hypothesis 5: Mood (level of emotional arousal) influences product choice.

\section{RESEARCH RESULTS AND DISCUSSION}

A combination of neuromarketing research methods allows identifying different sensory modalities at all stages of interaction with the product and measuring emotional reactions to it [Traindl, 2009, p. 110].

At Stage 1, we examined the visual perception of four product samples randomized in three virtual locations with synchronous registration of cognitive assessment of events (survey) (Table 2).

On Slide 1, the maximum duration of visual fixations was recorded for Sample 3 (Medovik, or Honey pie): the average fixation period was $558.92 \mathrm{msec}$, while the median value in the distribution was $448.50 \mathrm{msec}$, and the standard deviation was 672.6. On Slide 2, visual fixations were mostly concentrated on Sample 3 (Medovik) for $749.83 \mathrm{msec}$, while the median value was $315.0 \mathrm{msec}$, and the standard deviation was 821.3. Regardless of the product's locations, it turned out to be the most visually noticeable. On Slide 3, visual fixations were primarily focused on Sample 4 (Ptichye Moloko cake) for $1386 \mathrm{msec}$, while the median value was $1438 \mathrm{msec}$, and the standard deviation was 806.7.

The correlation matrix for the density of visual fixations depending on the sample number and its location on the slide showed the following dependencies. In its visual perception, Sample 3 (Medovik) is similar to Sample 4 (Napoleon cake). Pearson's $r$ is 0.85 , and the relationship 
Table 2 - Heat maps of fixations on product samples and cognitive assessment of the respondents' choice Таблица 2 - Тепловые карты фиксаций на образцах продуктов и когнитивная оценка выбора испытуемого

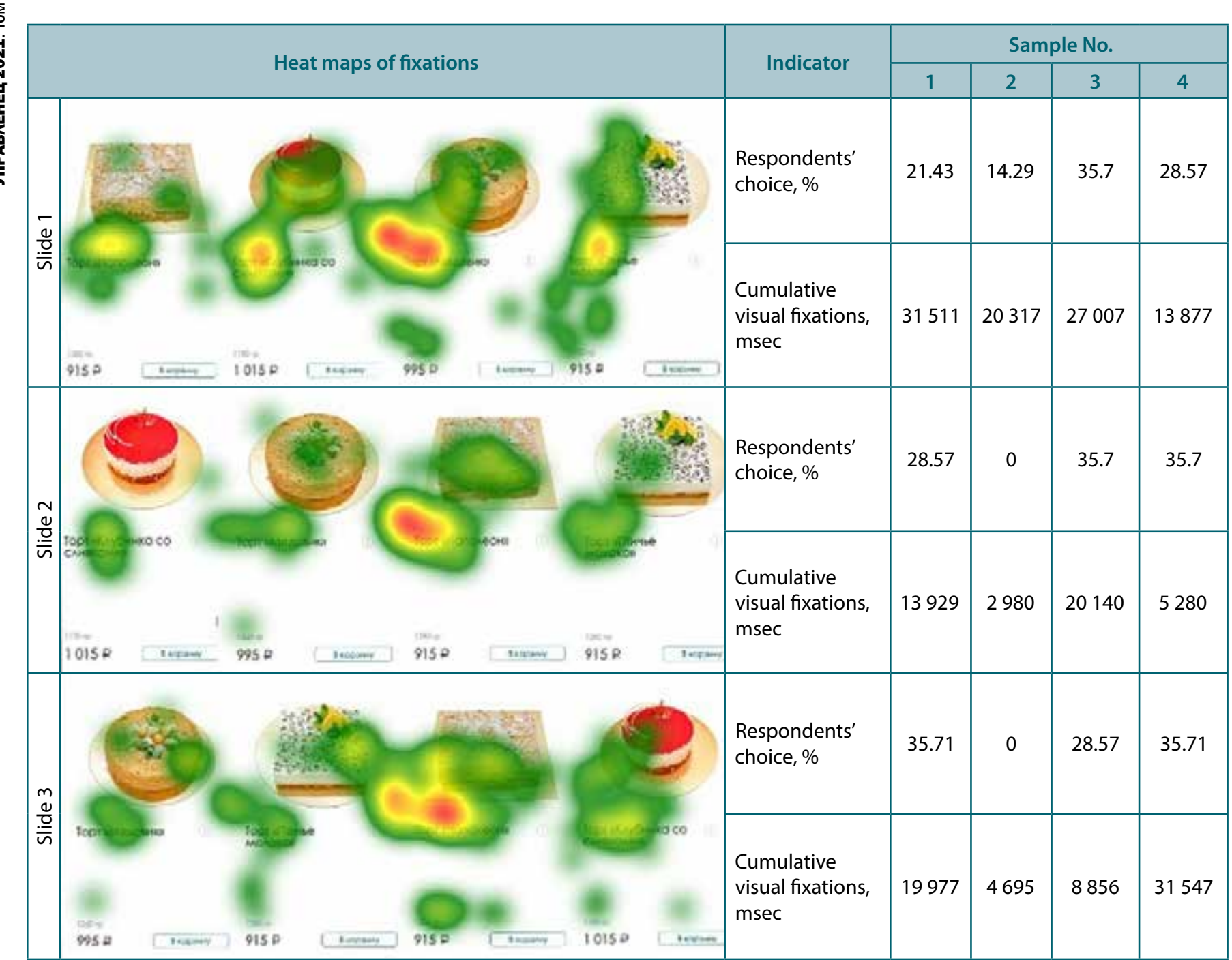

is strong. In accordance with their cognitive assessment, sample did not enjoy constant visual attention. Therefore, these two products were also prevalent in consumer pref- the ANOVA test was carried out to establish possible diferences. The survey shows that regardless of the location ferences in visual attention depending on the product loSample 4 (Ptichye Moloko cake) was in the lead, while this cation (Table 3).

Table 3 - ANOVA test results of the distributions of visual fixations on the samples under study Таблица 3 - Результаты дисперсионного анализа (ANOVA) распределений зрительных фиксаций по исследуемым образцам

\begin{tabular}{|c|c|c|c|c|c|}
\hline \multicolumn{2}{|l|}{ Eye tracking data } & Sum of squares & Mean square & $\mathrm{F}$ & Sig. \\
\hline \multirow{3}{*}{$\begin{array}{l}\text { Visual fixation: } \\
\text { Total fixation time on the selected area: } \\
\text { Sample } 1 \text { (Napoleon cake), msec }\end{array}$} & Between groups & 3345240.889 & 1672620.444 & 1.322 & 0.280 \\
\hline & Within groups & 41765546.083 & 1265622.609 & & \\
\hline & Total & 45110786.972 & & & \\
\hline \multirow{3}{*}{$\begin{array}{l}\text { Visual fixation: } \\
\text { Total fixation time on the selected area: } \\
\text { Sample } 2 \text { (Strawberry Cream cake), msec }\end{array}$} & Between groups & 968257.056 & 484128.528 & 2.521 & 0.096 \\
\hline & Within groups & 6337702.583 & 192051.593 & & \\
\hline & Total & 7305959.639 & & & \\
\hline \multirow{3}{*}{$\begin{array}{l}\text { Visual fixation: } \\
\text { Total fixation time on the selected area: } \\
\text { Sample } 3 \text { (Medovik cake), msec }\end{array}$} & Between groups & 2229041.722 & 1114520.861 & 2.716 & 0.081 \\
\hline & Within groups & 13541287.500 & 410342.045 & & \\
\hline & Total & 15770329.222 & & & \\
\hline \multirow{3}{*}{$\begin{array}{l}\text { Visual fixation: } \\
\text { Total fixation time on the selected area: } \\
\text { Sample } 4 \text { (Ptichye Moloko cake), msec }\end{array}$} & Between groups & 11756706.000 & 5878353.000 & 22.479 & 0.000 \\
\hline & Within groups & 8629798.750 & 261509.053 & & \\
\hline & Total & 20386504.750 & & & \\
\hline
\end{tabular}


The results of the analysis showed that differences were found only in Sample 4 (Ptichye Moloko cake) $p=0.00$, which is below the significance level of $p<0.05$ [Ivchenko, 2014, p. 37]. Hence, we can conclude that Hypothesis 1 is refuted, i.e. the virtual shelf placement of a product does not affect consumer choice, since they are guided by their own preferences. Indicators of the cognitive assessment of choice and visual attention to a product are statistically different. Thus, product visibility does not affect consumers' choice, and at the stage of purchase the stereotypical attitudes towards the product are of high importance; therefore, Hypothesis 2 is refuted. This fact is confirmed by Schifferstein et al. [2013, p. 18], who shows the relationship between cognitive judgments and direct sensory experience of consumption [Kahneman, 2020, p. 65].

At Stage 2, in order to examine Hypothesis 3, we analyzed an array of emotions expressed during the demonstration of ready-made meals. 11 slides were selected, and no randomization was used. In terms of gender groups, it can be seen that emotions communicated by male and female respondents were characterized by significant differences. The relationship between emotional states of both groups is statistically compared in Table 4.

The experiment showed that women were likely to express two emotions: enjoyment (the mean value of its occurrence probability was 32.76 with $S D=20.7$ ) and surprise (its mean value was 8.78 with $S D=2.84$ ). In men, ส enjoyment was less frequent and its probability was 16.01 with SD $=13.14$; for the emotion of surprise, its probability was 9.84 with $\mathrm{SD}=2.04$. Thus, Hypothesis 3 is partially confirmed that there are significant differences in emotional states of males and females when choosing a product online, but this is true for four emotions only (positive - surprise and enjoyment; negative - disgust and anger). Occurrence probability for the two other emotions - sadness and fear - is equal for both gender groups.

Analysis of emotional dynamics during the experiment revealed the following patterns.

In the first part of the experiment, men were more likely to express surprise and sadness; positive emotions were recorded during the second part of the observation (Fig. 1). At the same time, the cognitive assessment of the displayed slides was aimed mainly at the sensory perception of the product, its quality characteristics and usability.

Emotional dynamics in women was more positive. In most cases, they expressed enjoyment; at that, in the second part of the experiment the cognitive assessment was characterized by a decline in surprise (Fig. 2).

Having analyzed the emotional dynamics when displaying various visualizations of ready-made foods, we

Table 4 - Correlation between emotions expressed by male and female respondents Таблица 4 - Корреляционная зависимость между выраженными эмоциями мужчин и женщин

\begin{tabular}{|l|c|c|c|c|}
\hline \multicolumn{1}{|c|}{ Emotion } & $\begin{array}{c}\text { Pearson's } r \\
{[-1 \ldots+1]}\end{array}$ & Correlation level & $\begin{array}{c}\text { Kruskal-Wallis H test, } \\
\text { significance level }\end{array}$ & $\begin{array}{c}\text { Distribution differences } \\
p<0.05\end{array}$ \\
\hline Surprise & -0.876 & Strong & 0.02 & Present \\
\hline Sadness & -0.850 & Strong & 0.95 & Absent \\
\hline Enjoyment & 0.923 & Strong & 0.00 & Present \\
\hline Fear & 0.025 & No correlation & 0.26 & Absent \\
\hline Disgust & -0.343 & Very weak & 0.00 & Present \\
\hline Anger & -0.825 & Strong & 0.01 & Present \\
\hline
\end{tabular}

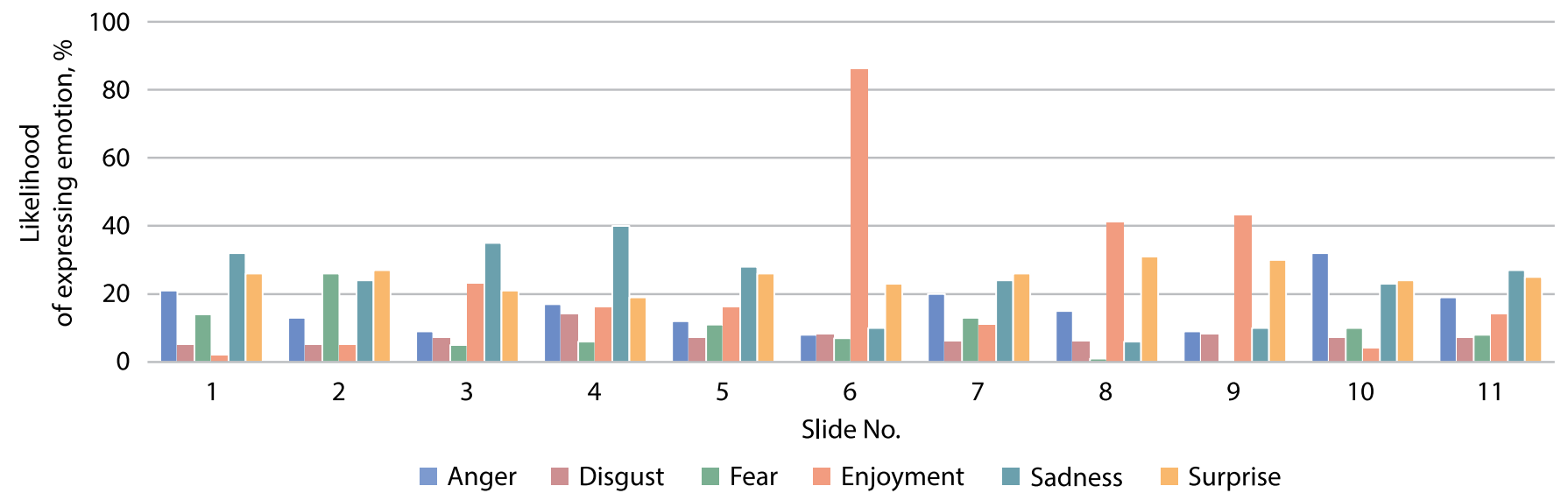

Fig. 1. Emotional dynamics in men during the experiment 


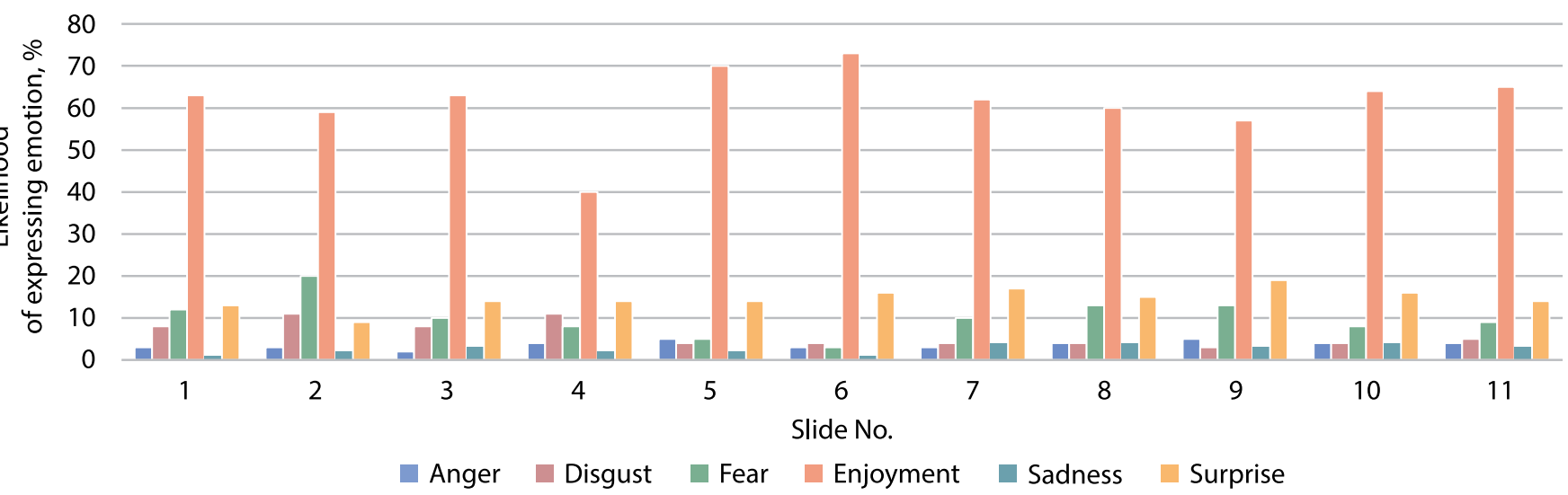

Fig. 2. Emotional dynamics in women during the experiment

Рис. 2. Эмоциональная динамика у женщин в процессе эксперимента

identified the most pronounced emotions on the slides. The visual collages were filtered by the mean values of occurrence probability of the six emotions according to the FACS system. In addition, a number of the slides were singled out allowing us to study the most pronounced emotions. One of the slides exhibited the peak values of two emotions simultaneously (Table 5).

Testing the normal distribution of occurrence probability of emotions according to the Kolmogorov-Smirnov test showed that for five emotions (anger, disgust, fear, sadness, and enjoyment) the distribution was not normal, therefore, nonparametric tests were applied in further analysis to test the similarity. The sixth emotion (surprise) was in line with normal distribution, and a parametric test was used for it.

1. In the given visualizations, the most frequent emotion is fear according to aggregate data with no gender categorization. It was recorded while demonstrating food stored in glass jars (Fig. 3, 4). This visualization was presented at the beginning of the experiment.

Table 5 - Peak values of occurrence probability of emotions Таблица 5 - Пиковые значения вероятности выраженности эмоций

\begin{tabular}{|c|c|c|c|c|c|c|c|c|}
\hline \multicolumn{2}{|r|}{ Valence of emotion } & Anger & Surprise & Sadness & Enjoyment & Fear & Disgust & Slide No. \\
\hline \multirow{6}{*}{ 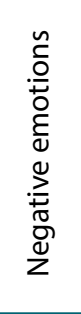 } & Mean value & 5.09340 & 9.49230 & 6.10740 & 24.59610 & 7.01430 & 5.63580 & \multirow{2}{*}{1} \\
\hline & Standard deviation & 2.73394 & 2.52199 & 4.38486 & 19.53291 & 4.21785 & 4.85187 & \\
\hline & Mean value & 5.54800 & 8.20940 & 6.14930 & 25.11480 & 5.61120 & 6.0054 & \multirow{2}{*}{2} \\
\hline & Standard deviation & 6.36008 & 2.03185 & 3.79317 & 18.60969 & 2.98231 & 4.09638 & \\
\hline & Mean value & 7.43010 & 9.43190 & 6.86740 & 24.77630 & 5.07500 & 4.27760 & \multirow{2}{*}{3} \\
\hline & Standard deviation & 5.40200 & 3.39133 & 4.99545 & 18.39930 & 3.05136 & 2.70132 & \\
\hline \multirow{4}{*}{ 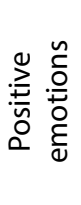 } & Mean value & 4.13260 & 8.68120 & 4.55830 & 35.9289 & 4.30550 & 5.78280 & \multirow{2}{*}{4} \\
\hline & Standard deviation & 1.39877 & 2.10459 & 4.42040 & 22.69081 & 2.40808 & 4.11146 & \\
\hline & Mean value & 3.86090 & 10.7434 & 5.01510 & 25.58990 & 4.25620 & 4.52450 & \multirow{2}{*}{5} \\
\hline & Standard deviation & 1.96167 & 3.21134 & 4.93069 & 16.29186 & 3.67636 & 2.30625 & \\
\hline
\end{tabular}
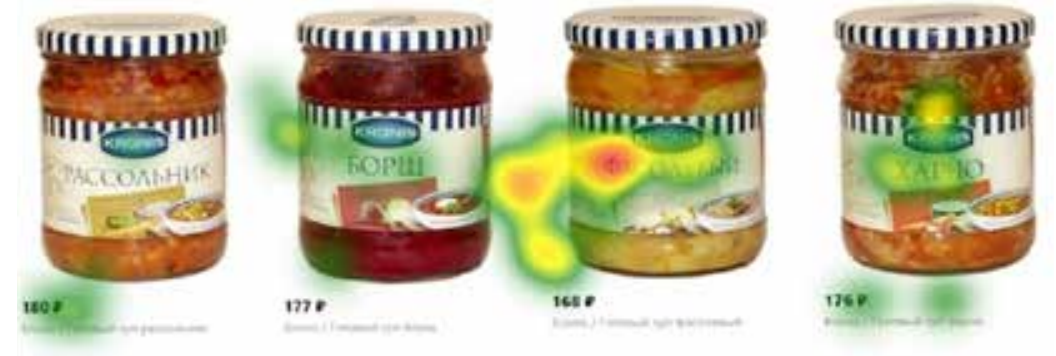

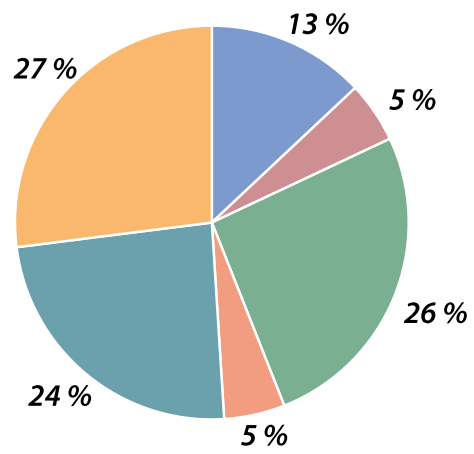

Anger

Disgust

Fear

Enjoyment

- Sadness

Surprise

Heat map of visual attention based on eye tracking data

An array of expressed emotions according to the FACS data

Fig. 3. Men's perception of the visualization of food stored in glass jars

Pис. 3. Восприятие мужчинами визуализации готовой еды в стеклянной таре 

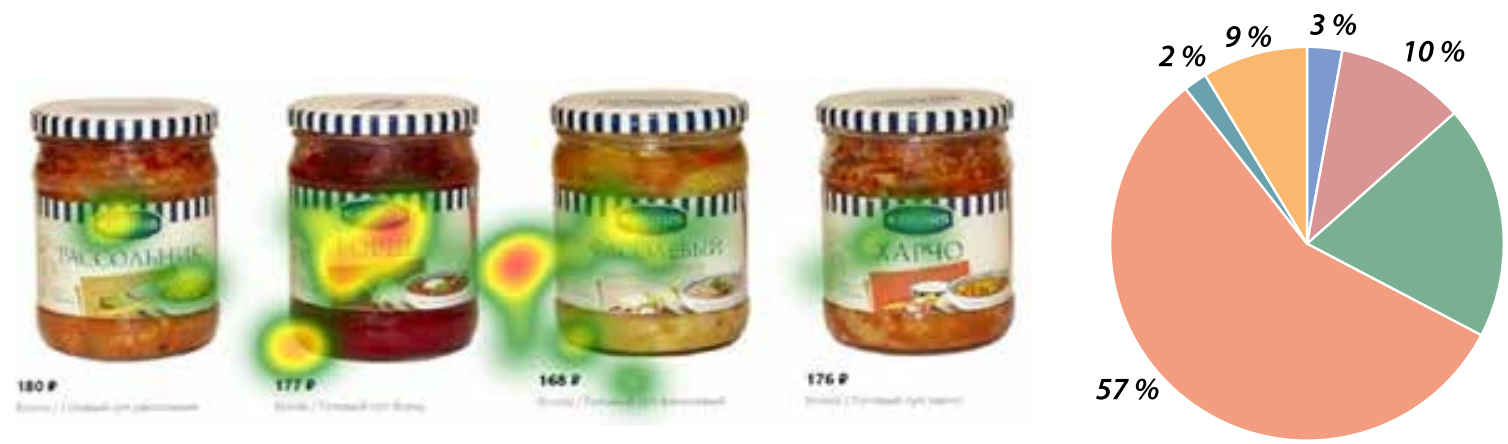

Heat map of visual attention based on eye tracking data

An array of expressed emotions according to the FACS data

Fig. 4. Women's perception of the visualization of food stored in glass jars

Рис. 4. Восприятие женщинами визуализации готовой еды в стеклянной таре

There are easily noticeable differences in the array of emotions expressed by men and women when studying the visualization. Analysis of the correlation relationship between the emotions of men and women showed a strong negative relationship: anger $\mathrm{R}=-0.795$; a moderate negative relationship in expressing enjoyment $\mathrm{R}=-0.460$; a moderate positive relationship in expressing sadness $R=0.43$; and a strong positive relationship for disgust $R=0.76$. No gender differences were observed for such emotions as fear and surprise. Comparison of distributions using the Mann-Whitney $U$ test showed a significance level $p=0.527$. This indicates that despite a significant difference in the mean values of occurrence probability of emotions in men and women, no statistically significant differences were found, and the hypothesis on their equality is accepted.

2. The highest probability of the emotion of disgust among the population under review was registered while studying homogonized first courses (Fig. 5, 6).

Comparison of probability distributions of the emotion of disgust using the Mann-Whitney $U$ test showed a significance level $p=0.154$. This signifies that the respondents' emotions are not statistically different. Analysis of correlation between emotions of men and women demonstrated a strong negative relationship: fear $R=-0.70$; a moderate negative relationship in express-
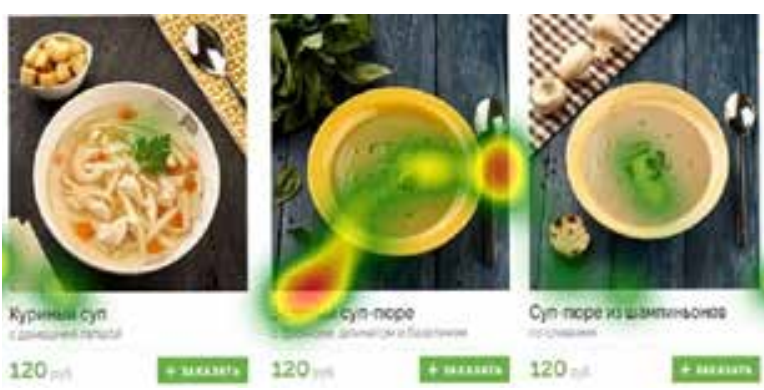

Heat map of visual attention based on eye tracking data
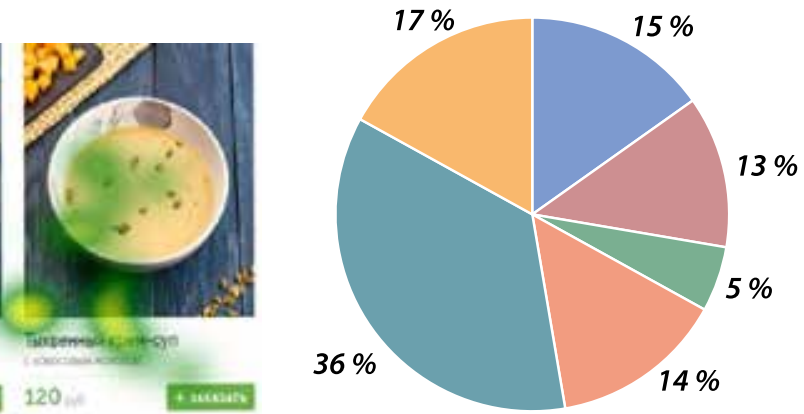

Anger

Disgust

Fear

Enjoyment

Sadness

Surprise

An array of expressed emotions according to the FACS data

Fig. 5. Men's perception of the visualization of homogonized first courses

Рис. 5. Восприятие мужчинами визуализации гомогонизированных первых блюд
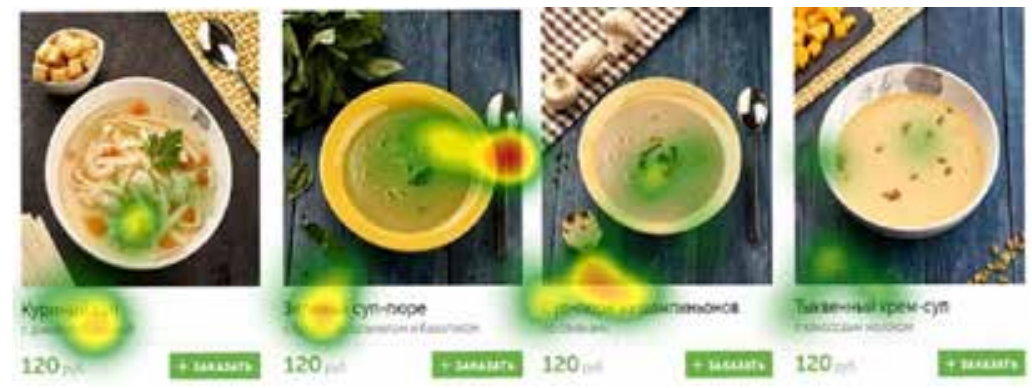

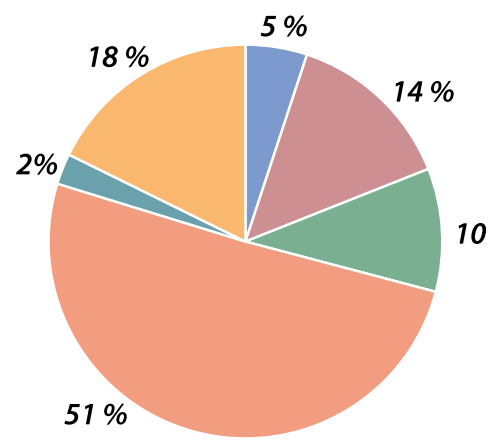

Anger

Disgust

Fear

Enjoyment

Sadness

Surprise

Heat map of visual attention based on eye tracking data

An array of expressed emotions according to the FACS data

Fig. 6. Women's perception of the visualization of homogonized first courses Рис. 6. Восприятие женшинами визуализации гомогонизированных первых блюд 
of ing sadness $R=-0.525$; and a strong positive relation* ship for disgust $R=0.94$. No gender correlation was $\sum_{\circ}^{5}$ found in the expression of such emotions as enjoyment ปे and surprise.

3. The similarity in expressing emotions was found using the correlation matrix (Fig. 7). It is worth noting that it is anger and sadness that demostrate a significant positive correlation at $R=0.726$. Therefore, these emotional states were analyzed together within the peak values of the same visualization.
Among the population under review, the highest occurrence probability of such emotions as anger and sadness was recorded when studying visualization of cake slices (Fig. 8, 9). According to the survey data, this slide provoked a negative reaction because the portions were small, excessive decoration was used, and half of the plate was occupied by ornaments but not the product.

Comparison of occurrence probability of the emotion of anger by gender using the Mann-Whitney $U$ test

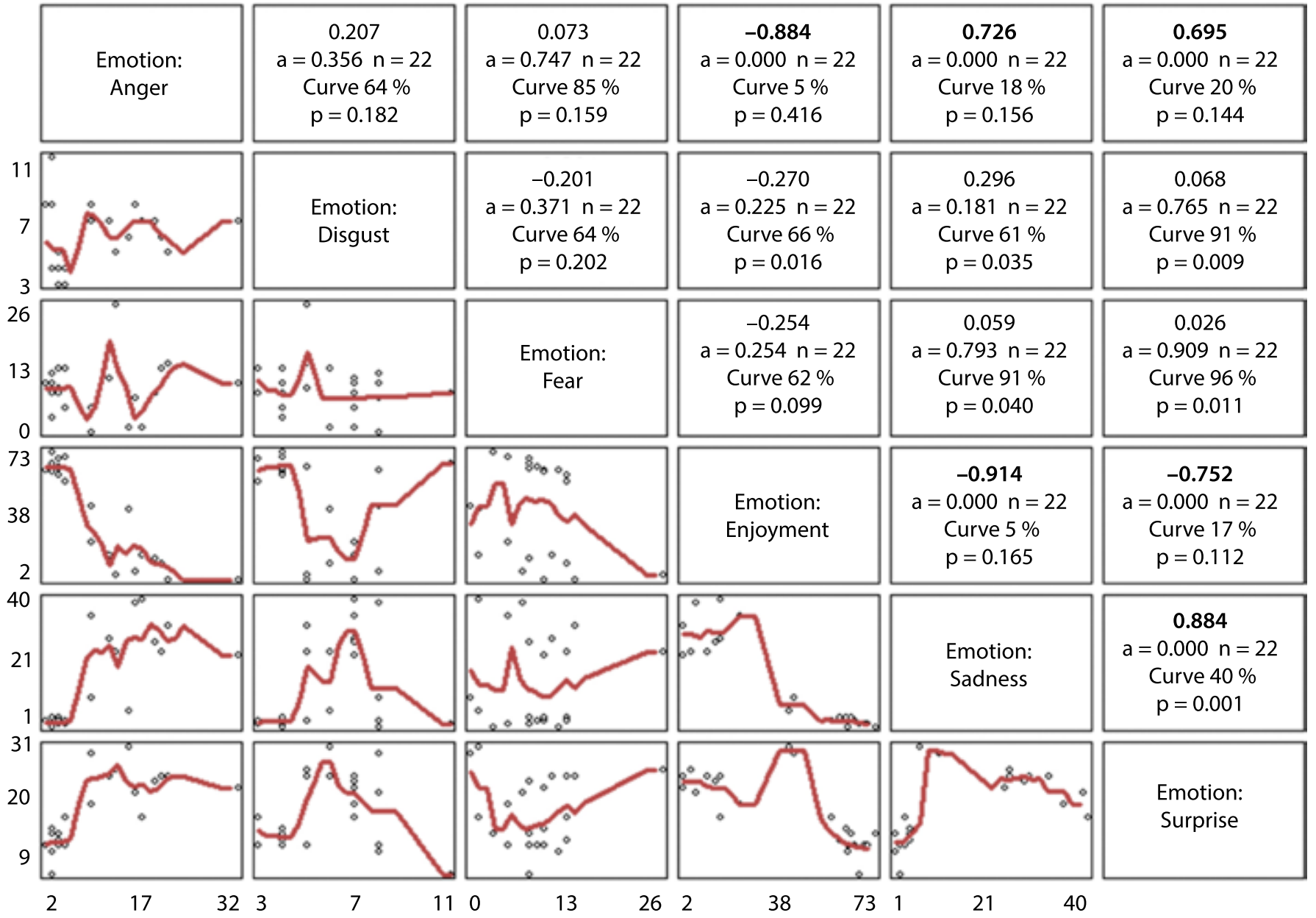

Fig. 7. Correlation matrix of emotions similarity Рис. 7. Корреляционная матрица схожести эмоций

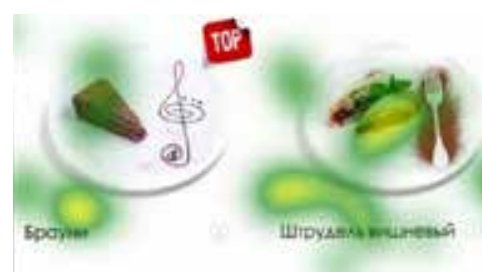

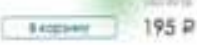

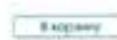

1850 185

Heat map of visual attention based on eye tracking data

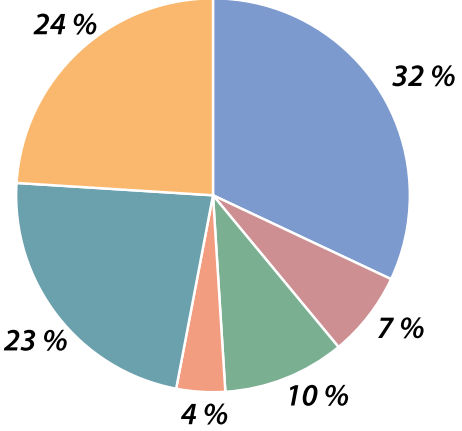

Anger

Disgust

Fear

Enjoyment

Sadness

Surprise

Fig. 8. Men's perception of the visualization of cake slices 

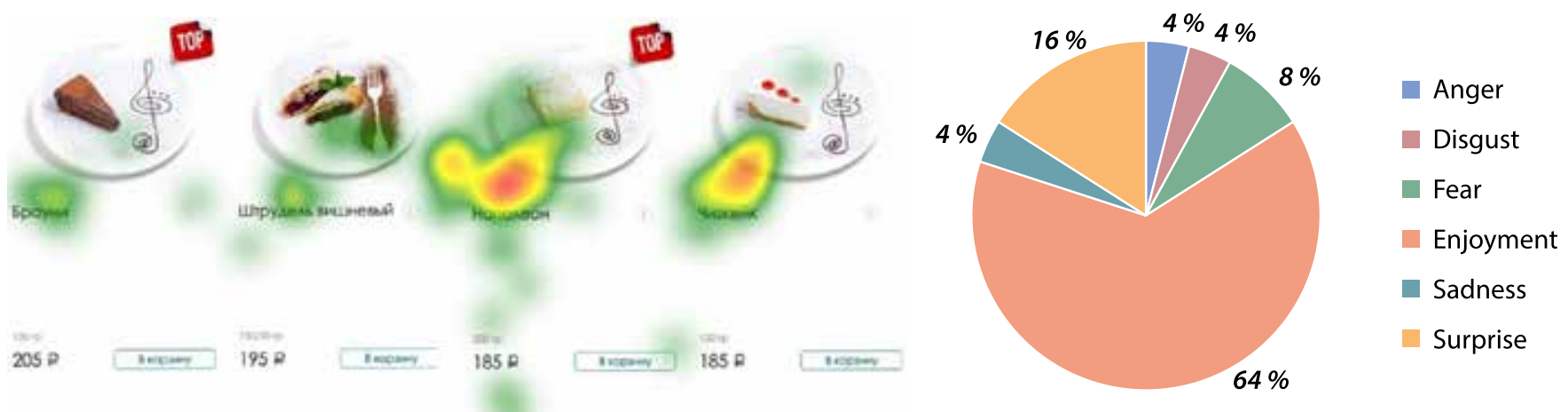

Heat map of visual attention based on eye tracking data

An array of expressed emotions according to the FACS data

Fig. 9. Women's perception of the visualization of cake slices

Рис. 9. Восприятие женщинами визуализации порционных тортов

showed a significance level $p=0.78$. This indicates that the respondents' emotions are not statistically different.

Analysis of correlation between emotions of men and women demonstrated a strong negative relationship: fear $\mathrm{R}=-0.89$; a moderate negative relationship in expressing enjoyment $R=-0.52$, surprise $R=-0.48$, and anger $R=-0.46$; a strong positive relationship for disgust $R=0.90$; and a moderate positive relationship for sadness $R=0.48$. No gender correlation was found in the expression of such emotions as enjoyment and surprise.
The results of the analysis illustrate that when selling a product online the plate it is served on should not be decorated with excessive ornaments thereby reducing the portion. The images should be large and accentuate the size of the portion.

4. The highest occurrence probability of the emotion of enjoyment was recorded for barbecue dishes. They were served not on plates but on wooden trays (Fig. 10,11).

Comparison of distributions using the Mann-Whitney $U$ test showed a significance level $p=0.047$. This indicates that the values of the probabilities of experi-
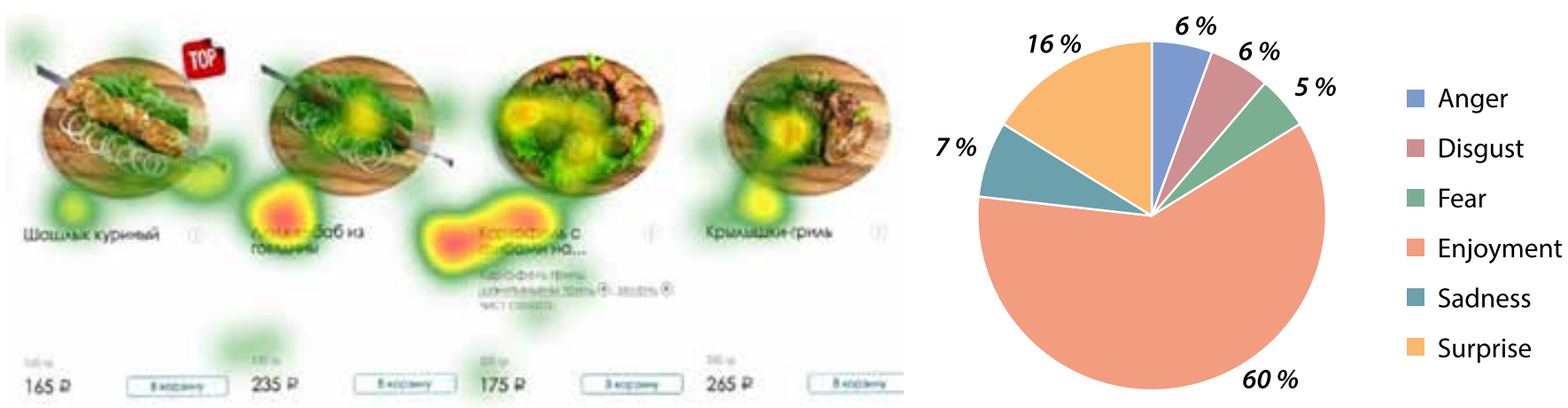

Heat map of visual attention based on eye tracking data

An array of expressed emotions according to the FACS data

Fig. 10. Men's perception of the visualization of barbecue Рис. 10. Восприятие мужчинами визуализации блюд, приготовленных на гриле
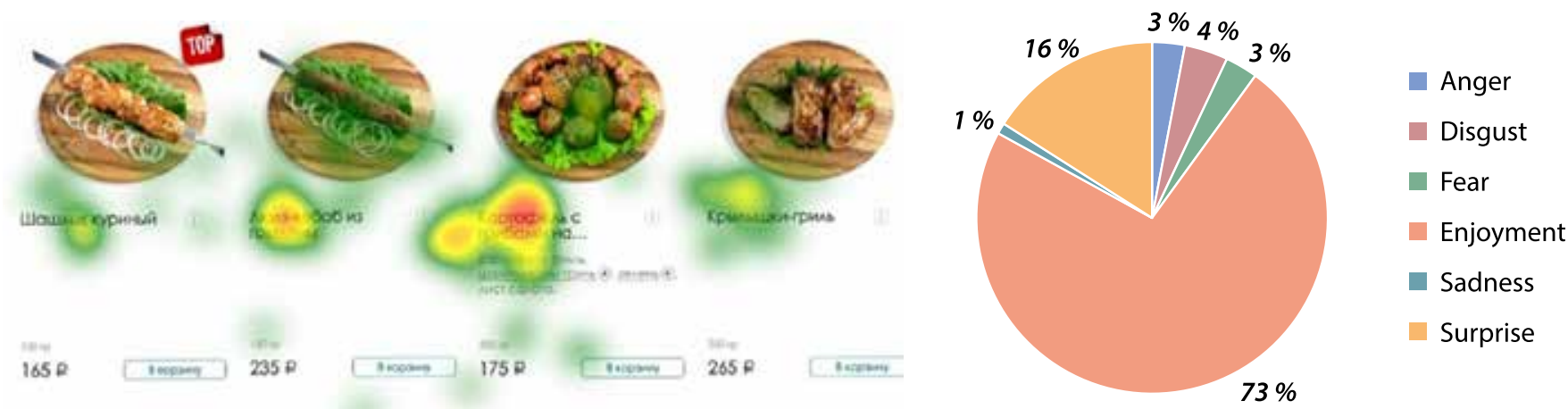

Heat map of visual attention based on eye tracking data

An array of expressed emotions according to the FACS data

Fig. 11. Women's perception of the visualization of barbecue

Рис. 11. Восприятие женщинами визуализации блюд, приготовленных на гриле 
enced emotions in men and women are statistically different. These data are partially confirmed by the correlation between the perception of different gender groups: a strong negative relationship in expressing enjoyment $R=-0.972$; a moderate negative relationship of surprise $R=-0.51$, and fear $R=-0.67$. For the rest of the emotions under consideration, no significant relationship was detected.

5. The last emotion analyzed was surprise. It was most clearly manifested while exploring complex meals with a variety of ingredients (Fig. 12, 13). The results showed cognitive dissonance which was possibly due to serving the products on plates of different colours and the sign "New" placed in the left upper corner.

Mean values compared using paired sample $t$-test showed that despite the difference in the mean values of emotions probability, no statistically significant differences were found. While examining the slide, men and women displayed the same intensity of surprise. Therefore, the hypothesis that emotions in men and women are similar is accepted.

These data are confirmed by the correlation between the perception of different gender groups: there is a strong positive relationship in expressing anger $R=0.98$, a moderate negative relationship of sadness $R=-0.56$ and fear $R=-0.48$. No significant correlation for the other emotions was observed.
The results of the analysis indicate that the antecedents of consumer choice are two basic positive emotions - surprise and enjoyment (Hypothesis 4). Typically, consumer choice is associated with a change in the emotional valence from disgust, fear and sadness to surprise and enjoyment. It is noteworthy that according to the experimental data it is surprise that mostly predetermines consumer choice. This might be due to the physiognomic manifestation that is similar to recognizing a product consumer intends to purchase.

When choosing ready-made food online, consumer tends to buy the products that they recognize, while displaying the emotion of surprise mixed with enjoyment.

Comparison of the factors prevailing when choosing a product, which are based on the cognitive assessment performed during the eye tracking and experimental study of autonomic reactions (Fig. 14), indicates that the main factors are taste preference, design, and placement.

The correlation between the product choice factors recorded verbally during the survey following the eye tracking experiment and autonomic responses (based on GSR and PPG) by Pearson's $r$ is $R=0,46$.

To examine the intensity of emotional arousal and test Hypothesis 5 to ascertain whether consumers' emotional arousal affects their product choices, the polygram data (Fig. 15) were included in the analysis, in particular, GSR and $P P G$ readings.
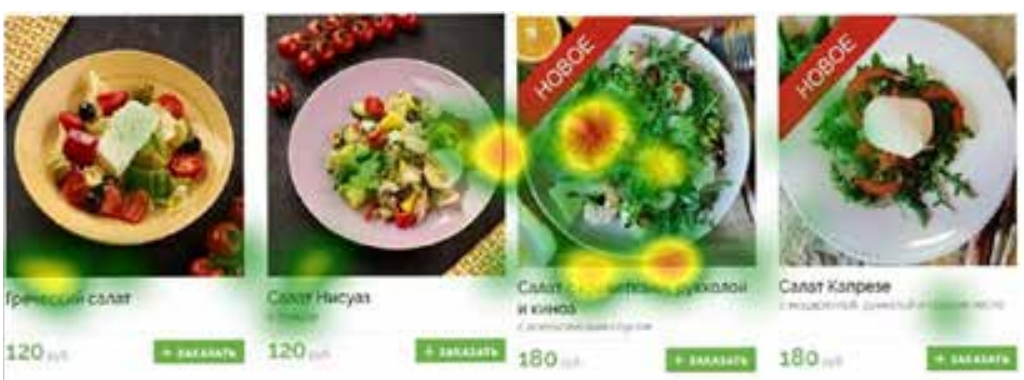

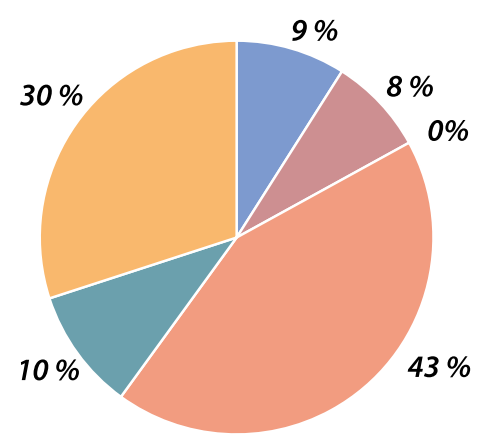

Heat map of visual attention based on eye tracking data

An array of expressed emotions according to the FACS data

Fig. 12. Men's perception of the visualization of complex meals

Puc. 12. Восприятие мужчинами визуализации многокомпонентных блюд
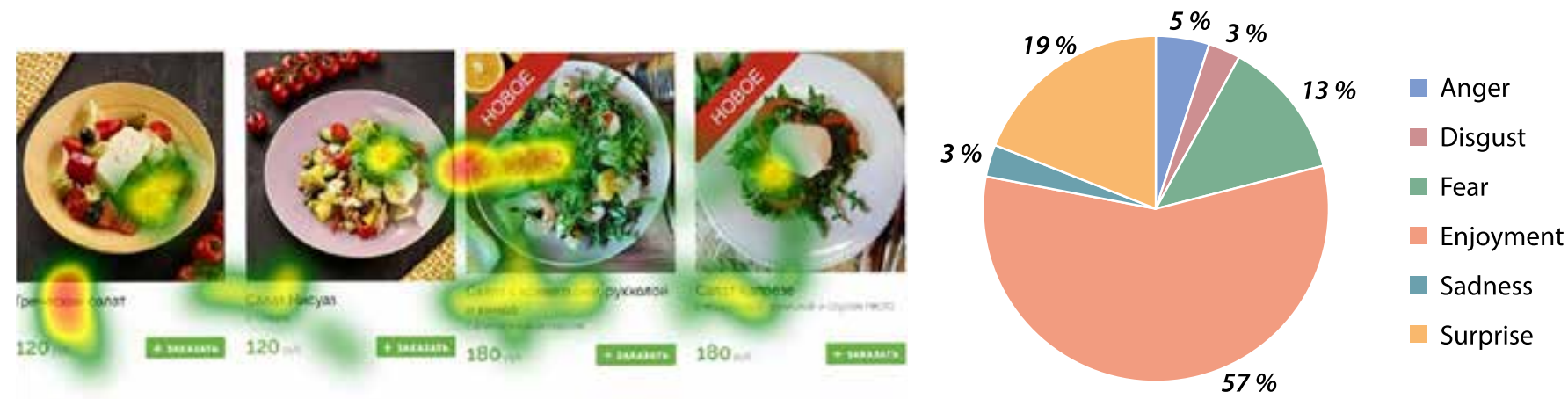

Heat map of visual attention based on eye tracking data

An array of expressed emotions according to the FACS data

Fig. 13. Women's perception of the visualization of complex meals Рис. 13. Восприятие женщинами визуализации многокомпонентных блюд 


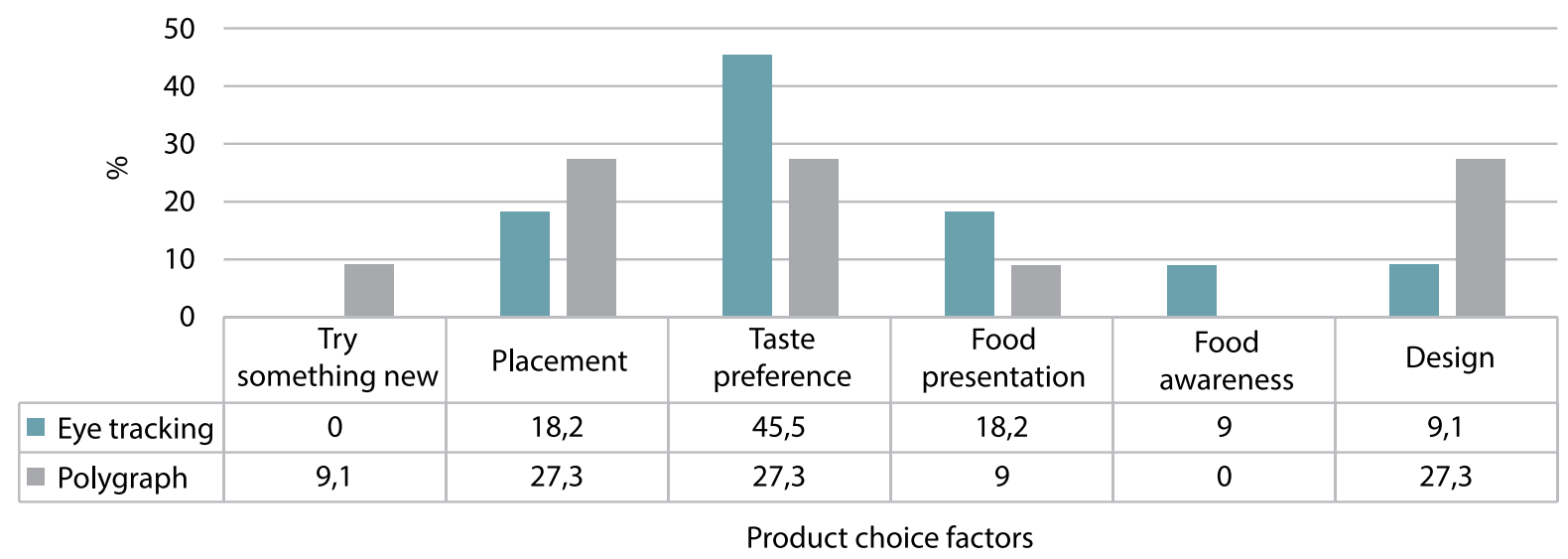

Fig. 14. Product choice factors based on the cognitive assessment and autonomic responses Рис. 14. Факторы выбора продукта по данным когнитивной оценки и вегетативных реакций

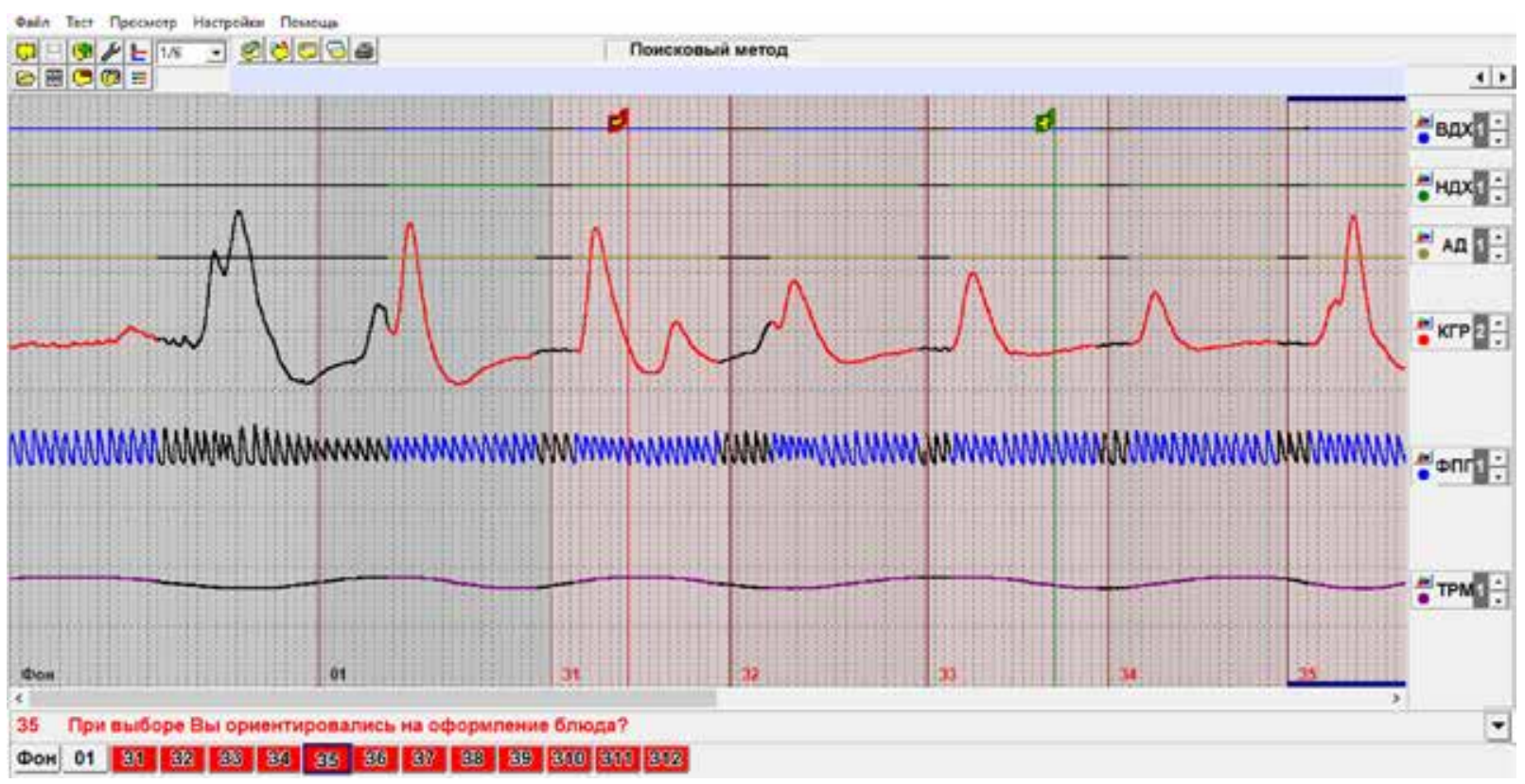

Fig. 15. Polygram with GSR and PPG signals

Puc. 15. Полиграмма с ритмами КГР и ФПГ

The relationship between respondents' emotional state and changes in their galvanic skin response was studied using linear regression analysis, where emotions were dependent variables, and GSR and PPG indicators were independent variables. The regression model was calculated using the SPSS software (Table 6).

Table 6 - Results of the regression model Таблица 6 - Результаты регрессионной модели

\begin{tabular}{|c|c|c|c|c|c|c|c|c|}
\hline \multicolumn{4}{|c|}{ Model summary } & \multicolumn{5}{|c|}{ ANOVA $^{a}$} \\
\hline Model & $\mathbf{R}^{\mathrm{a}}$ & $\begin{array}{c}R \\
\text { square }\end{array}$ & $\begin{array}{l}\text { Standard error } \\
\text { of the estimate }\end{array}$ & Model & $\begin{array}{c}\text { Sum } \\
\text { of squares }\end{array}$ & $F$ & $p^{\mathrm{b}}$ & Variable \\
\hline \multirow{3}{*}{ Fear } & \multirow{3}{*}{0.191} & \multirow{3}{*}{0.036} & \multirow{3}{*}{2.23} & Regression & 0.940 & \multirow{3}{*}{0.094} & \multirow{3}{*}{0.912} & a) Dependent variable: fear \\
\hline & & & & Residual & 24.910 & & & b) Prodictorc. (conctant) PPG CSR \\
\hline & & & & Total & 25.850 & & & 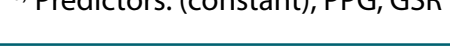 \\
\hline \multirow{3}{*}{ Enjoyment } & \multirow{3}{*}{0.742} & \multirow{3}{*}{0.550} & \multirow{3}{*}{16.863} & Regression & 1739.878 & \multirow{3}{*}{3.059} & \multirow{3}{*}{0.136} & a) Dependent variable: enjoyment \\
\hline & & & & Residual & 1421.866 & & & b) Predictorc. (ronctant) PPG GSR \\
\hline & & & & Total & 3161.744 & & & Predictors: (constant), PPG, GSR \\
\hline \multirow{3}{*}{ Disgust } & \multirow{3}{*}{0.658} & \multirow{3}{*}{0.433} & \multirow{3}{*}{2.59} & Regression & 25.805 & \multirow{3}{*}{1.911} & \multirow{3}{*}{0.242} & a) Dependent variable: disgust \\
\hline & & & & Residual & 33.765 & & & b) Predictorc. (ronctant) PPG GSR \\
\hline & & & & Total & 59.570 & & & 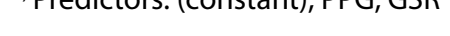 \\
\hline
\end{tabular}




\begin{tabular}{|c|c|c|c|c|}
\hline \multicolumn{4}{|c|}{ Model summary } & \multirow[b]{2}{*}{ Model } \\
\hline Model & $\mathrm{R}^{\mathrm{a}}$ & $\begin{array}{c}\mathbf{R} \\
\text { square } \\
\end{array}$ & $\begin{array}{l}\text { Standard error } \\
\text { of the estimate }\end{array}$ & \\
\hline \multirow{3}{*}{ Anger } & \multirow{3}{*}{0.931} & \multirow{3}{*}{0.867} & \multirow{3}{*}{1.096} & Regression \\
\hline & & & & Residual \\
\hline & & & & Total \\
\hline \multirow{3}{*}{ Surprise } & \multirow{3}{*}{0.709} & \multirow{3}{*}{0.503} & \multirow{3}{*}{1.95} & Regression \\
\hline & & & & Residual \\
\hline & & & & Total \\
\hline \multirow{3}{*}{ Sadness } & \multirow{3}{*}{0.491} & \multirow{3}{*}{0.241} & \multirow{3}{*}{2.909} & Regression \\
\hline & & & & Residual \\
\hline & & & & Total \\
\hline
\end{tabular}

1) according to Uchiyama [1992, p. 663], fear enhances the intensity of galvanic skin responses; however, when exploring ready-made food, this emotion is hardly displayed. Therefore, the regression model based on these data demonstrates lack of a significant relationship between emotion and GSR according to the multiple correlation coefficient $R=0.19$, and the multiple determination coefficient indicates that only $3.6 \%$ of the variance of the emotional state in the sample is due to the influence of emotional arousal level (GSR, PPG). The results of the ANOVA test show that no reliability was determined, the quality of the regression model for fear is low since $R^{2}=$ 0.036 , which is significantly less than 1 . The same is observed from the regression model's parameters;

2) the emotion of enjoyment is usually characterized by elevated heart rate and galvanic skin responses [Khalfa, 2008 , p. 17]. While examining ready-made food visualization, this emotion was one of the most intensive. The linear regression model for this emotion showed a significant positive multiple correlation $\mathrm{R}=0.742$ with signs of the emotional arousal strength. The coefficient of multiple determination $\mathrm{R}^{2}=0.55$ indicates that $55 \%$ of the variance of enjoinment indicators are due to the effect of autonomic reactions (independent variables GSR and PPG). At that, according to the values of the regression model's parameters and taking into account their statistical significance, GSR data have a greater effect on the emotional state than PPG;

3) as Collet [1997, p. 45] puts it, when investigating disgust, specific galvanic skin responses are observed such as an increase in skin temperature, and respiratory rate. Regression analysis data show that multiple correlation $\mathrm{R}=0.658$ has a significant positive relationship with GSR and PPG indicators. The coefficient of multiple determination $R^{2}=0.433$ suggests that $43 \%$ of the variance of disgust indicators are due to the intensity of emotional arousal. At the same time, no significant differences were
Окончание табл. 6

Table 6 (concluded)

\begin{tabular}{|c|c|c|c|}
\hline \multicolumn{4}{|c|}{ ANOVA $^{a}$} \\
\hline $\begin{array}{c}\text { Sum } \\
\text { of squares }\end{array}$ & $\mathbf{F}$ & $p^{b}$ & Variable \\
\hline 39.381 & \multirow{3}{*}{16.367} & \multirow{3}{*}{0.006} & a) Dependent variable: anger \\
\hline 6.015 & & & \multirow{2}{*}{ b) Predictors: (constant), PPG, GSR } \\
\hline 45.397 & & & \\
\hline 19.272 & \multirow{3}{*}{2.529} & \multirow{3}{*}{0.174} & \multirow{2}{*}{ a) Dependent variable: surprise } \\
\hline 19.053 & & & \\
\hline 38.324 & & & b) Predictors: (constant), PPG, GSR \\
\hline 13.422 & \multirow{3}{*}{0.793} & \multirow{3}{*}{0.502} & \multirow{2}{*}{ a) Dependent variable: sadness } \\
\hline 42.315 & & & \\
\hline 55.737 & & & b) Predictors: (constant), PPG, GSR \\
\hline
\end{tabular}

found according to the ANOVA test, since the significance level is $p=0.242$, which is greater than $p>0.05$;

4) one of the most pronounced emotions is anger, which is accompanied by more intense galvanic skin response than fear [Marci, 2007, p. 243]. In the present experiment, this emotion showed the strongest statically confirmed relationship with the strength of emotional arousal; the coefficient of multiple correlation was $R=0.93$, and the coefficient of multiple determination $\mathrm{R}^{2}=0.867$ confirmed that $86 \%$ of the variance in the manifestation of anger were due to the intensity of emotional arousal (GSR and PPG). As indicated by the ANOVA test, there are significant differences in the relationship between the two variables $p=0.006$, which is less than $p<0.05$;

5) according to Tsai [2000, p. 684], the emotion of surprise is considered of neutral valence. To determine it, additional studies are needed, since it is highly dependent on the context. Within the framework of the current research, this emotion was one of the most important predictors of consumer choice. A significant correlation was established with the level of emotional arousal, and the coefficient of multiple correlation was $R=0.70$. At the same time, the coefficient of multiple determination $R^{2}=$ 0.503 indicates that only half of the variance of surprise is due to the body's autonomic responses. No significant differences between the variables under discussion were found, since the significance level is $p=0.17$, which is greater than $p>0.05$;

6) as stated by Rottenberg [2002], sadness usually demonstrates a mixed galvanic skin response, which is associated with different forms of this emotion. For example, an elevated reaction is typical of crying, whereas a less strong reaction is characteristic of feeling sad. As for the visualization of ready-made meals, there is a moderate relationship with the intensity of emotional arousal; the coefficient of multiple correlation is $R=0.49$; the coefficient of multiple determination is $R^{2}=0.241$, which indicates that only $20 \%$ of the valence of this emotion are 
due to autonomic body reactions. The quality of the regression model for the emotion of sadness is insufficient, since $R^{2}=0.241$, which is less than 1 .

To establish the influence of fear and sadness on consumer choice, a number of clarifying experiments should be performed, since the quality of the regression models presented in the current analysis is insufficient to give unambiguous answers.

Thus, we can partly accept Hypothesis 5 that surprise and enjoyment, which are the most significant emotions when making product choice, are influenced by the level of emotional arousal (50-55 \% of cases).

Since consumer choice is made amid a wide array of emotional states, it is obvious that the intensity of emotional arousal will mostly affect negative emotions. This is possibly due to the fact that consumer choice is strongly affected by motivation. As confirmed in a number of studies (see, for example, [Murray, 2012, p. 39]), the level of emotional arousal has a direct effect on product choice. People tend to rely on their current affective state when choosing a product, therefore, those in a positive mood will prefer products enhancing it, while those experiencing negative emotions are prone to choose products incompatible with the current level of emotional arousal.

\section{CONCLUSION}

As a result of the study, we can arrive at the following conclusions.

1. We have rejected the hypothesis that when choosing ready-made food on the web the virtual shelf placement had an effect on the purchasing intent. Regardless of the product randomization, the indicators of the cognitive assessment of choice and visual attention to the product were statistically different.

2. The hypothesis about the correlation between product visibility and product choice was refuted. It has been statistically proven that consumers mainly chose those products that they already knew; mostly they demonstrated searching eye movement behavior.

3. It has been partially confirmed that for four out of the six emotions there was significant differences in the emotional states of male and female respondents when choosing ready-made meals online (positive - surprise and enjoyment, and negative - disgust and anger); the other two emotions - sadness and fear - were equally observed in both gender groups.
4. The hypothesis about the effect of emotions on consumer choice has been statistically confirmed. The research results have demonstrated that the predictors of consumer choice were two basic positive emotions such as surprise and enjoyment. Typically, consumer choice is associated with change in the valence of emotions from disgust, fear and sadness to surprise and enjoyment. According to experimental data, it was the emotion of surprise that served as a predictor of consumer choice. This could be due to the similarity between the physiognomic manifestation of this emotion and the recognition of a product that a person intended to purchase. Thus, when choosing ready-made food on the Internet, consumers tend to buy the products they already know while demonstrating surprise mixed with enjoyment.

5. It has been partially confirmed that the intensity of emotional arousal affected product choice. The study has revealed that surprise and enjoyment, which were the most significant emotions when making product choice, were influenced by the level of emotional arousal (50-55\% of cases). Consumer experiences a wide range of emotions of different valence and intensity, while in most cases they are guided by what is familiar to them. It is the products that consumers have already tried seem attractive to them and trigger the purchasing intent.

Presumably, such a consumer behavior is due to the fact that online buyers do not have an opportunity to test organoleptic features of the product. It is rather difficult to transfer product properties using only visual images, since the technological problem of the limited Internet interface for transmitting signals to all the senses of the buyer has not yet been resolved. Nevertheless, thanks to the awareness of the fundamental emotional predictors of consumer choice, it is possible to adjust the emotional state through advertising. According to Nielsen ${ }^{1}$, ads with the best emotional response generated a $23 \%$ lift in sales. To promote brand-new products, it is necessary to make advertising emotional and capable of enhancing positive feelings. Such advertising should contain elements that cause surprise and enjoyment, since these emotions can increase website conversion.

\footnotetext{
${ }^{1}$ We're ruled by our emotions, and so are the ads we watch. https://www.nielsen.com/us/en/insights/article/2016/were-ruledby-our-emotions-and-so-are-the-ads-we-watch/
} 
Morin C., Renvoise P. (2020). The Persuasion Code: How Neuromarketing Can Help You Persuade Anyone, Anywhere, Anytime (Russ. ed.: Morin C., Renvoise P. Kod ubezhdeniya. Kak neyromarketing povyshaet prodazhi, effektivnost' reklamnykh kampaniy i konversiyu sayta. Saint Petersburg: Piter).

Traindl A. (2009). Neuromarketing. Die innovative visualisierung von emotionen (Russ. ed.: Traindl A. Neyromarketing: vizualizatsiya emotsiy. Moscow: Alpina Publishers).

Yarosh O.B., Kalkova N.N., Mitina E.A., Eremenko Yu.A., Velgosh N.Z. (2020). Vizualnyy neyromarketing: fundamental'nye i prikladnye issledovaniya [Visual neuromarketing: Basic and applied research]. Simferopol: ARIAL.

Yarosh O.B., Kalkova N.N., Reutov V.E. (2020). Upravlenie vizual'nym vnimaniem potrebitelya v usloviyakh informatsionnoy asimmetrii [Managing consumers' visual attention in the context of information asymmetry]. Upravlenets - The Manager, vol. 11, no. 5, pp. 97-111. DOI: 10.29141/2218-5003-2020-11-5-8.

Aharonson V., Nehmadi N., Messer H. (2007). Automatic emotional stimulus identification from facial expressions. Proceedings of the Fourth Conference on IASTED International Conference: Signal Processing, Pattern Recognition, and Applications (Innsbruck, Austria, February). ACTA Press, Anaheim, CA. Pp. 333-337.

Barnes C., Southee C., Henson B. (2003). The impact of affective design of product packaging upon consumer purchase decisions. Proceedings of the 2003 International Conference on Designing Pleasurable Products and Interfaces (Pittsburgh, PA, USA, June). DPPI ‘03. ACM, New York, NY. Pp. 134-135.

Bindu M.H., Gupta P., Tiwary U.S. (2007). Cognitive Model-Based Emotion Recognition from Facial Expressions for Live Human Computer Interaction. Proceedings of the 2007 IEEE Symposium on Computational Intelligence in Image and Signal Processing (CIISP 2007). Pp. 351-356.

Boehner K., DePaula R., Dourish P., Sengers P. (2007). How emotion is made and measured. International Journal of HumanComputer Studies, vol. 65, no. 4, pp. 275-291. https://doi.org/10.1016/j.ijhcs.2006.11.016.

Collet C., Vernet-Maury E., Delhomme G., Dittmar A. (1997). Autonomic nervous system response patterns specificity to basic emotions. Journal of Autonomic Nervous System, vol. 62, pp. 45-57. DOI: 10.1016/s0165-1838(96)00108-7.

Consoli D. (2009). Emotions that influence purchase decisions and their electronic processing. Annales Universitatis Apulensis Series Oeconomica, vol. 11, no. 2, pp. 996-1008. DOl:10.29302/oeconomica.2009.11.2.45.

Darwin C. (1904). The Expression of the Emotions in Man and Animals. 2nd ed. London: J. Murray. Pp. $43-67$.

Descartes R. (1989). Passions of the Soul. Hackett Publishing Company. Pp. 24-34.

Dornaika F., Davoine F. (2008). Simultaneous Facial Action Tracking and Expression Recognition in the Presence of Head Motion. International Journal of Computer Vision, vol. 76, no. 3, pp. 257-281. https://doi.org/10.1007/s11263-007-0059-7.

Ekman P., Friesen W.V. (1977). Manual for the Facial Action Coding System. Consulting Psychologists Press.

Hess U., Kappas A., McHugo G.J., Lanzetta J.T., Kleck R.E. (1992). The facilitative effect of facial expression on the self-generation of emotion. International Journal of Psychophysiology, vol. 12, pp. 251-265.

Highfield R., Wiseman R., Jenkins R. (2009). How your looks betray your personality. New Scientist, issue 2695.

Jordan P.W. (2001). Pleasure with products: The new human factors. User interface Design for Electronic Appliances. Bristol, PA: Taylor \& Francis. Pp. 303-328.

Khalfa S., Roy M., Rainville P., Bella S.D., Peretz I. (2008). Role of tempo entrainment in psychophysiological differentiation of happy and sad music? International Journal of Psychophysiology, vol. 68, no. 1, pp. 17-26. DOI: 10.1016/j.ijpsycho.2007.12.001.

Marci C.D., Glick D.M., Loh R., Dougherty D.D. (2007). Autonomic and prefrontal cortex responses to autobiographical recall of emotions. Cognitive, Affective, and Behavioral Neuroscience, vol. 7, no. 3, pp. 243-250. https://doi.org/10.3758/CABN.7.3.243.

Murray K. (2012). An Arousal Regulation Explanation of Mood Effects on Consumer Choice. Journal of Consumer Research, vol. 39, no. 3, pp. 574-584. DOI: 10.1086/664040.

Nielsen J., Landauer T.K. (1993). A mathematical model of the finding of usability problems. CHI '93: Proceedings of the INTERACT'93 and CHI '93 Conference on Human Factors in Computing Systems (Amsterdam, April 24-29). Pp. 206-213. https://doi. org/10.1145/169059.169166.

Parrott W.G. (2000). Emotions in social psychology: Essential readings. Psychology Press, Philadelphia. Pp. 34-51.

Plutchik R. (1997). The circumplex as a general model of the structure of emotions and personality. Circumplex models of personality and emotions. Washington, DC: American Psychological Association. Pp. 17-45.

Rottenberg J., Gross J.J., Wilhelm F.H., Najmi S., Gotlib I.H. (2002). Crying threshold and intensity in major depressive disorder. Journal of Abnormal Psychology, vol. 111, no. 2, pp. 302-312. https://doi.org/10.1037/0021-843X.111.2.302.

Samal A., lyengar P.A. (1992). Automatic Recognition and Analysis of Human Faces and Facial Expressions: A Survey. Pattern Recognition, vol. 25, issue 1, pp. 65-77. https://doi.org/10.1016/0031-3203(92)90007-6.

Schifferstein R., Fenko A., Desmet P., Labbe D., Martin N. (2013). Influence of package design on the dynamics of multisensory and emotional food experience. Food Quality and Preference, vol. 27, issue 1, pp. 18-25. DOI: 10.1016/j.foodqual.2012.06.003.

Tsai J.L., Levenson R.W., Carstensen L.L. (2000). Autonomic, subjective and expressive responses to emotional films in older and younger Chinese Americans and European Americans. Cultural Diversity and Ethnic Minority Psychology, vol. 15, no. 4, pp. 684-693. DOI: 10.1037//0882-7974.15.4.684.

Uchiyama I. (1992). Differentiation of fear, anger, and joy. Perceptual and Motor Skills, vol. 74, no. 2, pp. 663-667. https://doi. org/10.2466/pms.1992.74.2.663. 
Ивченко Ю.С. (2014). Статистика. Москва: РИОР; ИНФРА-М.

\section{Источники}

Канеман Д. (2020). Думай медленно... решай быстро. Москва: АСТ.

Мазур Е.Е. (2012). «Эмоциональный маркетинг»: миф или новая маркетинговая концепция? // Маркетинг в России и за рубежом. № 1. С. 16-26.

Моосмюллер Г., Ребик Н.Н. (2018). Маркетинговые исследования с SPSS. Москва: ИНФРА-М.

Морен К., Ренвуазье П. (2020). Код убеждения. Как нейромаркетинг повышает продажи, эффективность рекламных кампаний и конверсию сайта. Санкт-Петербург: Питер.

Трайндл А. (2009). Нейромаркетинг: визуализация эмоций. Москва: Альпина Паблишерз.

Ярош О.Б., Калькова Н.Н., Митина Э.А., Еременко Ю.А., Вельгош Н.3. (2020). Визуальный нейромаркетинг: фундаментальные и прикладные исследования. Симферополь: ИТ «АРИАЛ».

Ярош О.Б., Калькова Н.Н., Реутов В.Е. (2020). Управление визуальным вниманием потребителя в условиях информационной асимметрии // Управленец. Т. 11, № 5. С. 97-111.

Aharonson V., Nehmadi N., Messer H. (2007). Automatic emotional stimulus identification from facial expressions. Proceedings of the Fourth Conference on IASTED International Conference: Signal Processing, Pattern Recognition, and Applications (Innsbruck, Austria, February). ACTA Press, Anaheim, CA. Pp. 333-337.

Barnes C., Southee C., Henson B. (2003). The impact of affective design of product packaging upon consumer purchase decisions. Proceedings of the 2003 International Conference on Designing Pleasurable Products and Interfaces (Pittsburgh, PA, USA, June). DPPI'03. ACM, New York, NY. Pp. 134-135.

Bindu M.H., Gupta P., Tiwary U.S. (2007). Cognitive Model-Based Emotion Recognition from Facial Expressions for Live Human Computer Interaction. Proceedings of the 2007 IEEE Symposium on Computational Intelligence in Image and Signal Processing (CIISP 2007). Pp. 351-356.

Boehner K., DePaula R., Dourish P., Sengers P. (2007). How emotion is made and measured. International Journal of HumanComputer Studies, vol. 65, no. 4, pp. 275-291. https://doi.org/10.1016/j.ijhcs.2006.11.016.

Collet C., Vernet-Maury E., Delhomme G., Dittmar A. (1997). Autonomic nervous system response patterns specificity to basic emotions. Journal of Autonomic Nervous System, vol. 62, pp. 45-57. DOI: 10.1016/s0165-1838(96)00108-7.

Consoli D. (2009). Emotions that influence purchase decisions and their electronic processing. Annales Universitatis Apulensis Series Oeconomica, vol. 11, no. 2, pp. 996-1008. DOI:10.29302/oeconomica.2009.11.2.45.

Darwin C. (1904). The Expression of the Emotions in Man and Animals. 2nd ed. London: J. Murray. Pp. $43-67$.

Descartes R. (1989). Passions of the Soul. Hackett Publishing Company. Pp. 24-34.

Dornaika F., Davoine F. (2008). Simultaneous Facial Action Tracking and Expression Recognition in the Presence of Head Motion. International Journal of Computer Vision, vol. 76, no. 3, pp. 257-281. https://doi.org/10.1007/s11263-007-0059-7.

Ekman P., Friesen W.V. (1977). Manual for the Facial Action Coding System. Consulting Psychologists Press.

Hess U., Kappas A., McHugo G.J., Lanzetta J.T., Kleck R.E. (1992). The facilitative effect of facial expression on the self-generation of emotion. International Journal of Psychophysiology, vol. 12, pp. 251-265.

Highfield R., Wiseman R., Jenkins R. (2009). How your looks betray your personality. New Scientist, issue 2695.

Jordan P.W. (2001). Pleasure with products: The new human factors. User interface Design for Electronic Appliances. Bristol, PA: Taylor \& Francis. Pp. 303-328.

Khalfa S., Roy M., Rainville P., Bella S.D., Peretz I. (2008). Role of tempo entrainment in psychophysiological differentiation of happy and sad music? International Journal of Psychophysiology, vol. 68, no. 1, pp. 17-26. DOI: 10.1016/j.ijpsycho.2007.12.001.

Marci C.D., Glick D.M., Loh R., Dougherty D.D. (2007). Autonomic and prefrontal cortex responses to autobiographical recall of emotions. Cognitive, Affective, and Behavioral Neuroscience, vol. 7, no. 3, pp. 243-250. https://doi.org/10.3758/CABN.7.3.243.

Murray K. (2012). An Arousal Regulation Explanation of Mood Effects on Consumer Choice. Journal of Consumer Research, vol. 39, no. 3, pp. 574-584. DOI: 10.1086/664040.

Nielsen J., Landauer T.K. (1993). A mathematical model of the finding of usability problems. CHI '93: Proceedings of the INTERACT'93 and CHI '93 Conference on Human Factors in Computing Systems (Amsterdam, April 24-29). Pp. 206-213. https://doi. org/10.1145/169059.169166.

Parrott W.G. (2000). Emotions in social psychology: Essential readings. Psychology Press, Philadelphia. Pp. 34-51.

Plutchik R. (1997). The circumplex as a general model of the structure of emotions and personality. Circumplex models of personality and emotions. Washington, DC: American Psychological Association. Pp. 17-45.

Rottenberg J., Gross J.J., Wilhelm F.H., Najmi S., Gotlib I.H. (2002). Crying threshold and intensity in major depressive disorder. Journal of Abnormal Psychology, vol. 111, no. 2, pp. 302-312. https://doi.org/10.1037/0021-843X.111.2.302.

Samal A., lyengar P.A. (1992). Automatic Recognition and Analysis of Human Faces and Facial Expressions: A Survey. Pattern Recognition, vol. 25, issue 1, pp. 65-77. https://doi.org/10.1016/0031-3203(92)90007-6.

Schifferstein R., Fenko A., Desmet P., Labbe D., Martin N. (2013). Influence of package design on the dynamics of multisensory and emotional food experience. Food Quality and Preference, vol. 27, issue 1, pp. 18-25. DOI: 10.1016/j.foodqual.2012.06.003.

Tsai J.L., Levenson R.W., Carstensen L.L. (2000). Autonomic, subjective and expressive responses to emotional films in older and younger Chinese Americans and European Americans. Cultural Diversity and Ethnic Minority Psychology, vol. 15, no. 4, pp. 684-693. DOI: 10.1037//0882-7974.15.4.684.

Uchiyama I. (1992). Differentiation of fear, anger, and joy. Perceptual and Motor Skills, vol. 74, no. 2, pp. 663-667. https://doi. org/10.2466/pms.1992.74.2.663. 


\section{Information about the authors Информация об авторах}

\section{Olga B. Yarosh}

Dr. Sc. (Econ.), Professor of Marketing, Trade and Customs Dept., Chief Researcher of the Laboratory of Neuromarketing and Behavioral Economics of the Institute of Economics and Management. V.I.Vernadsky Crimean Federal University (21/4 Sevastopol St., Simferopol, 295015, Russia).E-mail: iarosh.olga@gmail.com.

\section{Natalia N. Kalkova}

Cand. Sc. (Econ.), Associate Professor of Marketing, Trade and Customs Dept., Leading Researcher of the Laboratory of Neuromarketing and Behavioral Economics of the Institute of Economics and Management. V.I. Vernadsky Crimean Federal University (21/4 Sevastopol St. Simferopol, 295015, Russia). E-mail: nkalkova@yandex.ru.

\section{Viktor E. Reutov}

Dr. Sc. (Econ.), Professor, Head of Marketing, Trade and Customs Dept., Head of the Institute of Economics and Management. V.I. Vernadsky Crimean Federal University (21/4 Sevastopol St., Simferopol, 295015, Russia).E-mail: reutov@ieu.cfuv.ru.

\section{Ярош Ольга Борисовна}

Доктор экономических наук, профессор кафедры маркетинга, торгового и таможенного дела, главный научный сотрудник Лаборатории нейромаркетинга и поведенческой экономики Института экономики и управления. Крымский федеральный университет им. В.И. Вернадского (295015, РФ, г. Симферополь, ул. Севастопольская, 21/4). E-mail: iarosh.olga@gmail.com.

\section{Калькова Наталья Николаевна}

Кандидат экономических наук, доцент кафедры маркетинга, торгового и таможенного дела, ведущий научный сотрудник Лаборатории нейромаркетинга и поведенческой экономики Института экономики и управления. Крымский федеральный университет им. В.И. Вернадского (295015, РФ, г. Симферополь, ул. Севастопольская, 21/4). E-mail: nkalkova@yandex.ru.

\section{Реутов Виктор Евгеньевич}

Доктор экономических наук, профессор, заведующий кафедрой маркетинга, торгового и таможенного дела, директор Института экономики и управления. Крымский федеральный университет им. В.И. Вернадского (295015, РФ, г. Симферополь, ул. Севастопольская, 21/4). E-mail: reutov@ieu.cfuv.ru. 